\title{
Biocompatibility of a New Generation of Covered Metallic Biliary Stents in a Treatment of Malignant Causes Irreversibile Cholestasis
}

\author{
Vesna M. Vilendečić ${ }^{1}$, Željko Ž. Markovićn ${ }^{1,2}$, \\ Biljana B. Marković Vasiljkovići, , Dragan M. Mašulovićc ${ }^{1,2}$ \\ ${ }^{1}$ Clinical Center of Serbia, Center for Radiology and MRI, 11000 Belgrade, Serbia \\ ${ }^{2}$ University of Belgrade, School of Medicine, 11000 Belgrade, Serbia
}

\section{SUMMARY}

Introduction: Overview of periprocedural and postprocedural (early and late) complication giving us access to determine the biological effects of treatment with covered versus uncovered metal stents in patients with irreversible jaundice malignant etiology.

The Aim: The aim of study was to compare the clinical therapeutical effects of covered billiary stents versus uncovered billiary stents.

Subjects and methods: We treated two groups of patients with irreversible cholestasis malignant etiology. In the first group of patients were used metal covering stents (MCS), while in the other group used metal uncovered stents (MNS).

Results: We observed periprocedural complications, technical complications, and the early-to 30-day and late-to 6 months post-procedural complications such as parameters of biocompatibility of inserted endoprosthesis, i.e. biological effects on surrounding tissues. We found statistically high difference in the occurrence of bleeding and periprocedural complications in total of MNS group. In the category of early postprocedural complications, we found a statistically significant difference in the MNS groups for a hemobilia, post-stent cholangitis, stent occlusion, irritative symptoms and appetite loss, and also in the overall appearance of early postprocedural complications in MNS. In the category of late postprocedural complications statistically significant difference we found in the MNS reobstructive cholangitis, reobstruktive jaundice, irritative symptoms, loss of appetite and in full. The cause of stent dysfunction-obliteration, biliary encrustation, ingrowth, overgrowth and mucosal hyperplasia, tells us in favor of the biological effects of the insertion, point applied prosthesis and the final therapeutic effect achieved by them.

Conclusions: According to our results, taking into account the parameters of biocompatibility under applicable definitions, authors can conclude that covered stents in contrast to the uncovered are meeting the criteria of almost ideal biological prostheses.

Keywords: biocompatibility, biologically effects, biological systems, metal stent, covered stent, irreversible cholestasis, malignant etiology 


\section{INTRODUCTION}

Biocompatibility is a term that will surely mark the technical achievements and aspirations in medicine and biological systems of the $21^{\text {th }}$ century. Where the conventional pharmacology and surgery can give the therapeutic contribution, technology biocompatible device system is imposed as the only solution, and perhaps the best they can. Precondition that determines the success of any therapeutic device system is exactly biocompatibility. The extent to which the system will be suitable device specific biological systems is a key concept in many research,experimental and clinical. There are many definitions of the term biocompatibility. It is define as a the property of being biologically compatible and not producing a toxic, injurious, or immunological response in living tissue. As a result of its strength and biocompatibility, the material is often used in medical devices. Some other definitions are: the ability to coexist with living organisms without harming them; the quality of not having toxic or injurious effects on biological systems. The degree of biocompatibility depends on a material's chemical stability over time, tendency to cause inflammation, incite disease, or become carcinogenic.

Biomaterials and its behavior in various contexts is related to biocompatibility. The term-biocompatibility may refer to specific properties of a material without specifying where or how the material is used (for example, that it elicits little or no immune response in a given organism, or is able to integrate with a particular cell type ortissue), or to more empirical clinical success of a whole device in which the material or materials feature. Quiddity of the term is laying in double meaning how biomaterials interact with thehuman bodyand, also, how those interactions determine the clinical success of a medical device. It is the main reason why modern medical devices and prostheses are often made of more than one material so it might not always be sufficient to talk about the biocompatibility of a specific material [1]. It is not adequate to determine the biocompatibility of single material in relation to a single cell type of tissue, because of the immune response and reparatory function of the body which are complicated. According to ISO 10993 or other similar standards, there are a lot of in vitro tests to determine if a certain material or biomedical products (such as pacemaker, hip replacement, stent etc.) is biocompatible, but not the biocompatibility of a material. They towards the animal testing and finally clinical trials that will determine the biocompatibility of the material in a given application and thus medical devices such as implants or drug delivery devices. It is the most important step in medicotechnologically evolution of some device.

The biocompatibility as a term has been mentioned for the first time in the peerreview journals and meetings in 1969/1970 $[2,3]$, almost two decades before it began to be commonly used in scientific literature. Williams regarded factors which determine clinical success. The main thing for an implant, regarding to this author, is not to have to be positively bioactive but not to do any harm. Williams definition, which was defined in the European Society for Biomaterials Consensus Conference, and definition from "The Williams dictionary of Biomaterials" is "The ability of a material to perform with an appropriate host response in a specific application" $[4,5]$. The other one from the same dictionary is "The quality of not having toxic or injurious effects on biological systems". Comparison of the tissue response produced through the close association of the implanted candidate material to its implant site within the host animal to that tissue response recognized and established as suitable with control materials - ASTM. The ASTM is not recommended according to Williams Dictionary since it only refers to local tissue responses, in animal models. Refers to the ability of a biomaterial to perform its desired function with respect to a medical therapy, without eliciting any undesirable local or systemic effects in the recipient or beneficiary of that therapy, but generating the most appropriate beneficial cellular or tissue response in that specific situation, and optimizing the clinically relevant performance of that therapy [6]. It is more precious version of the first definition. One more definition is "Biocompatibility is the capability of a prosthesis implanted in the body to exist in harmony with tissue without causing deleterious changes" all these definitions claim that the material is the point of every device system. It is the reason why much of the preclinical testing of the material is not conducted on the devices but rather the material itself. Testing has to include the shape, geometry and surface treatment of the device will also affect its biocompability. In the litera- 
ture, one quite often stumbles upon the adjective form: biocompatible. However, according to Williams' definition, this does not make any sense because biocompatibility is contextual, i.e. much more than just the material itself will determine the clinical outcome of the medical device of which the biomaterial is a part. This also points to one of the weaknesses with the current definition because a medical device usually is made of more than one material.

The scope of the first definition is so wide that Williams tried to find suitable subgroups of applications in order to be able to make more narrow definitions [6]. In this article, the chosen subgroups and their definitions were: 1. Biocompatibility of long - term implanted - The biocompatibility of a long-term implantable medical device refers to the ability of the device to perform its intended function, with the desired degree of incorporation in the host, without eliciting any undesirable local or systemic effects in that host; 2. Biocompatibility of short-term implantable devices - The biocompatibility of a medical device that is intentionally placed within the cardiovascular system for transient diagnostic or therapeutic purposes refers to the ability of the device to carry out its intended function within flowing blood, with minimal interaction between device and blood that adversely affects device performance, and without inducing uncontrolled activation of cellular or plasma protein cascades; 3 . Biocompatibility of tissue - engineeringproducts - The biocompatibility of a scaffold or matrix for a tissue - engineering products refers to the ability to perform as a substrate that will support the appropriate cellular activity, including the facilitation of molecular and mechanical signaling systems, in order to optimize tissue regeneration, without eliciting any undesirable effects in those cells, or inducing any undesirable local or systemic responses in the eventual host.

Medical grade siliconesaresiliconestested forbiocompatibilityand are appropriate to be used for medical applications. In the United States, the Food and Drug Administration (FDA) regulates materials implanted into the body [1]. Medical grade silicones are generally grouped into three categories: nonimplantable, short term implantable and longterm implantable. Materials approved as USP Class V and VI can be considered medical grade [7]. Most medical grade silicones are at least Class VI certified. Silicone suppliers and some silicone prototyping companies provide guidelines for material use [8].

Polyethylene (abbreviated PE) or polythene [IUPAC name polyethene or poly (methylene)] is the most common plastic. Many kinds of polyethylene are known, with most having the chemical formula $\left(\mathrm{C}_{2} \mathrm{H}_{4}\right)_{n} \mathrm{H}_{2}$. Thus PE is usually a mixture of similar organic compoundsthat differ in terms of the value of nit is biodegrading plastics. In May 2008, Daniel Burd, a 16-year-old Canadian, won the Canada-Wide Science Fair in Ottawa after discovering that Pseudomonas fluorescens, with the help of Sphingomonas, can degrade over $40 \%$ of the weight of plastic bags in less than three months.

Application of metal alloys in the manufacture of prostheses for the use in medicine is defined in the International Standards Organization for Standardization in Medicine (ISO standards) and the decisions of the European Committee for Standardization in medicine (CEN standards). The most common metal alloy stent materials such as: ferum-chromium-nickel, cobalt-chrome, titanium and nitinol. In the period 1988-1991, metal stents were predominantly produced from surgical any steel (ISO 10993 - 316L) which is the dominant element iron (65.6\%) and chromium (17\% responsible for corrosion resistance) and nickel (14\% responsible for the stability metal alloys). The middle of the last decade of the last century, the expansion of the application had cobalt-chromium alloys (Palmatz stent, Cordis J \& J) and alloys of titanium with $88.5 \%$ (Strecker stent, BS), which is composed not iron, nickel and chromium.In 1996, the largest application has had this type of stent.Today the dominant material for the metal stents has alloy nitinol. Nitinol stents dwelling build from about equal amounts of nickel and titanium with less $1 \%$ of the composition of the alloy participate iron, magnesium, cobalt and chromium. All biliary stents characterized by antimagnetizm, corrosion resistance and the capacity to reduce local aggregation of blood elements. These characteristics constitute the notion biocompatibility prosthesis. In relation to the manner of insertion of stents used in hepatobiliary recanalization can be balloon expandible or selfexpandible. Incomparably greater usage in all indications has selfexpandable stents. Due to the passage through the soft tissue structures of the liver, as well as the way through parenchyma, and 
when changing the direction of penetration, the case of application of a stent balloon-expandable possible possibility of moving the catheter and the stent along its dislocation before insertion, as in the case of application selfexpandible stents not happen.

Metal stents in interventional radiology are applied almost twenty years. All the time we have witnessed continuous development expansion of this method of recanalization. Stent materials, corrosion resistance, design, insertion systems and all other aspects of importance for the therapeutic effectiveness continually refined through an extraordinary interdisciplinary scientific integration [9]. A small number of other methodologies in clinical medicine that are so hyperactive unified way superior technology of biocompatible materials and medical knowledge. It is appropriate that there is a continuous expansion of good therapeutic results, decreasing the number of relapses and a set of criteria which distinguish the ideal stent increased. Acquired numerous clinical experiences [10], and formed the impression that certain traditional qualifying runs for irreversible biliary strictures main choledoch or some of its branches now changing. Pushing the boundaries of medical biological relativity to omnipotence, metal stents have become one of differentiation specificity of modern medicine at the end of this century.

Significant contribution in metallic prostheses relations to the use of so-called covered stent for selective use of the biliary insertion $2003^{\text {rd }}$ years (Wallstent biliary endoprosthesis covering and Unistep and Ultraflex cover diamond biliary stent system - BS). In our hospital from March 2006, we used the covered biliary stents Allium length of $10 \mathrm{~cm}$ and a width of $8 \mathrm{~mm}$. Allium stents were selfexpandible nitinol covered with a biocompatible polyurethane and silicon. Placing stents in cancer patients is usually performed to treat advanced nonresectable tumors, but in some cases the stent is placed as a "bridge" to surgery. The main advantage of covered stents is that there is no option for ingrowing tissue reactive proliferation and progression of infiltration. Clinical trials are aimed, in the context of assessment material, testing of materials and their behavior in biological tissue. Stents, as a metal prosthesis, covered and uncovered, and their biocompatibility may be discussed from the point of complicating (periprocedural, technical and postprocedural, early and late) as a reaction to the surrounding tissue and causes dysfunctional as the ultimate therapeutically effect realized in the particular circumstances.

\section{THE AIM}

The aim of study was to compare the clinical therapeutical effects of covered billiary stents versus uncovered billiary stents.

\section{MATERIALS AND METHODS}

This paper is academic, a phase IV study, done in accordance with the EU Directives and with current legislative and government regulations of the Republic of Serbia [11]. The study has been approved by the Ethics Committee of the Faculty of Medicine, University of Belgrade, Serbia (No. 29/VI-2). All data and the personal information collected in this study are subject to medical confidentiality and may only be brought together for processing and evaluation in an anonymous form.

The survey included patients treated at the department of interventional radiology and the department of digestive radiology Clinical Center of Serbia in the period from October 2006 to October 2011, who were diagnosed as biliary tract obstruction and propagation malignancies: cholangiocarcinoma, pancreatic carcinoma, gall bladder carcinoma, gastric cancer and metastases in the hilum of the liver.

Two groups of 29 patients with irreversible cholestasis malignant etiology, we applied the treatment with metal stents, uncovered Balton biliary stent ${ }^{\oplus}$ (Balton, Poland) or Wallstent ${ }^{\circledast}$ (Boston Scientific, USA), and covered Allium biliary stent ${ }^{\bullet}$ (Hedera, Israel). The Allium self-expandable, large caliber fully covered and easily removable biliary stents were designed to be used in chronic Common Bile Duct (CBD) obstructions for allowing intra-luminal flow duringits long indwelling period (up to 6 months). They are made of a super-elastic alloy (nitinol) fully covered by a novel polymeric material for preventing tissue ingrowth and reduce occlusion by sludge. Their $8 \mathrm{~mm}$ or $10 \mathrm{~mm}$ diameterallows excellent intra-luminal flow. The specially designed proprietaryend elementsminimize reactive tissue proliferation. The anchored model has a low radial force sphincteric segment to prevent or minimize the reflux which is the main cause of 
cholangitis seen with conventional stents. The deployment procedure can be performed using the standard ERCP procedure or percutaneously (depending on the deployment system used). The Allium Biliary Stents are designed to be removed easily and safely. The main stent characteristics areindicated for all strictures in the common bile duct, large caliber for intraluminal flow, long dwelling time, endoscopic or Trans-Hepatic insertion, easy insertion and stent positioning, available with or without an anchor, no tissue in-growth, anti-reflux design, easy removal of the device. Complications may develop during positioning, usually being recognized immediately by the operator, or may be detected after placement by diagnostic imaging as early (first 30 days after placement) or late (> 30 days) events.

Evaluation included radiographic, $\mathrm{CT}$ and exciting ultrasonic control to evaluate the position and patency of the stent functions. Subscriptions are periprocedural complications (TA fall, jump TA, over sedation, pain, bleeding, contrast artifacts, fever, irritability) and technical complications related to the technique of insertion (catheter dislocation, dislocation of the guide wires, repuncture, catapulting the stent, stent incomplete distension). Besides periprocedural were measured and postprocedural complications (early and late). Early procedural complica-

Table 1. Distribution of patients by age, sex, diagnosis and state of mind at the time of intervention.

*data presented as $\mathrm{X} \pm \mathrm{SD}$

HC - cholangiocarcinoma,

PHC - head of pancreas cancer,

GBC - gallbladder cancer,

GC - gastric cancer,

SD - secondary deposits in the liver hilum.

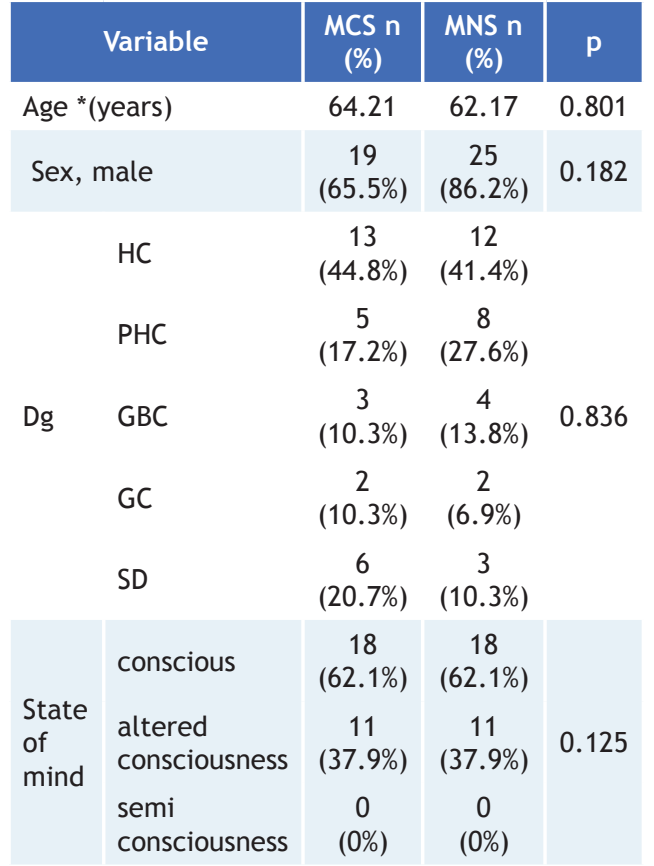

tions (cholangitis, abscess, acute cholecystitis, biliary perforation, pleural emphysema, haemobilia, intraperitoneal pulse, subcutaneous metastases, poststent cholangitis, percutaneous fistula,stent occlusion, irritative symptoms and loss of appetite), made up to a month after stent insertion. Late complications (reobstructive jaundice, reobstructive cholangitis, acute cholecystitis, chronic bleeding and melena, duodenal ulcer or perforation, stent migration path forward, pancreatitis, fistula, percutaneous, irritative symptoms and loss of appetite) incurred in the periodfrom one month to six months after insertion. As predictors constant of dysfunctional accompanied by obliteration of the stent, ingrowth, overgrowth, mucosal hyperplasia and biliary encrustation.

\section{Statistical analysis}

Descriptive statistics were presented as mean values with standard deviation (SD) for numeric variables, or as absolute numbers with percentages for categorical variables.Differences in continuous variables between the groups were compared using the Students ttest or the Mann-Whitney U test (for skewed data). Differences between the categorical data were tested by the Chi-square test and/or Fisher's exact test where appropriate; $p$ value $<0,05$ were considered statistically significant.

\section{RESULTS}

Patients were divided into two groups according to the type of intervention/dentures that were treated (MCS - metal covered stents, uncovered/noncovered stents - MNS). The distribution of patients by age, sex, diagnosis and state of mind at the time of intervention is shown in table 1 . There were significantly more males but there was no difference in the distribution of poles per group. Patients were nearly identical states of consciousness in groups. The pathological substrate occurs in five entities - cholangiocarcinoma, pancreatic cancer, stomach cancer, gallbladder and secondary deposits in the hilum of the liver - with no statistically significant differences in distribution between groups.

Complications are parameter of implants biocompatibility in the broader context of the word. Therefore, a good part of the research devoted to technical screening, periprocedural and postprocedural, early (30 
days) and late (30 days to 6 months) complications. Periprocedural complications like bleeding fully exhibit highly statistically significant difference between the groups (table 2). In a group of technical complications, were no statistical differences, except in incomplet stent distension (table 3). Technical success was achieved in $100 \%$ (29/29), so stent incomplete distension isn't occurred.

Table 4 presents the distribution of early postprocedural complications in groups. Our experience indicates conclusion that the new Allium biliary covered stent allows a minimally invasive, ambulatory approach to recurrent biliary strictures with very satisfactory results comparable with earlier generation of biliary stents, metal uncovered stents. In the category of early postprocedural complications (table 4). Postprocedural complications, early (table 4) haemobilia, poststent cholangitis, occlusion of the stent, irritative symptoms, loss of appetite and early post-procedural complications in its entirety are fully statistical significantly different distributed by groups. Late post-procedural complications reopstructive jaundice, reopstructive cholangitis, irritative symptoms, loss of weight and late post-procedural complications in their entirety are presented with statistically significant differences in groups (table 5).

Cause of stent dysfunction-obliteration, biliary encrustration, ingrowth, overgrowth and mucosal hyperplasia, tells us in favor of the biological effects in insertion place applied prosthesis and the final therapeutic effect achieved by them. All causes of stent dysfunctional (table 6) considered in two groups treated with covered and non-covered stents recorded a statistically significant difference at all, except for biliary encrustations.Reintervention significantly differently distributed in groups, showing both weekly. Lethal outcome is the same in groups and presented by weeks in that record. Since the early and late postprocedural complication to a lesser extent occur in MPS, and also records the significantly smaller number of causes dysfunctional of stent in the same group and a smaller number of reintervention.

\section{DISCUSSION}

The results obtained in this study confirm the hypothesis that the first line therapy in the treatment of jaundice and irreversible malig-

\begin{tabular}{|l|r|r|c|}
$\begin{array}{l}\text { periprocedural } \\
\text { complication }\end{array}$ & \multicolumn{1}{|c|}{ MPS } & \multicolumn{1}{c|}{ MNS } & \multicolumn{1}{c|}{$\mathrm{P}$} \\
\hline TA fall & $6(20.7 \%)$ & $8(27.6 \%)$ & 0.501 \\
\hline Jump TA & $9(31.0 \%)$ & $10(34.5 \%)$ & 0.950 \\
\hline Oversedation & $3(10.3 \%)$ & $4(13.8 \%)$ & 0.689 \\
\hline Pain & $10(34.5 \%)$ & $13(44.8 \%)$ & 0.253 \\
\hline $\begin{array}{l}\text { Bleeding } \\
\text { Contrast }\end{array}$ & $3(10.3 \%)$ & $11(37.9 \%)$ & 0.042 \\
\hline artifacts & $5(17.2 \%)$ & $4(13.8 \%)$ & 0.387 \\
\hline Fever & $12(41.4 \%)$ & $9(31.0 \%)$ & 0.368 \\
\hline Irritability & $7(24.1 \%)$ & $13(44.8 \%)$ & 0.235 \\
\hline TOTAL & $18(62.1 \%)$ & $26(89.7 \%)$ & 0.046 \\
\hline
\end{tabular}

\begin{tabular}{l|c|c|c|}
\hline $\begin{array}{l}\text { technical } \\
\text { complication }\end{array}$ & MPS & MNS & p \\
\hline $\begin{array}{l}\text { Catheters } \\
\text { dislocation }\end{array}$ & $3(10.3 \%)$ & $5(17.2 \%)$ & 0.748 \\
$\begin{array}{l}\text { Guide wires } \\
\text { dislocation }\end{array}$ & $6(20.7 \%)$ & $4(13.8 \%)$ & 0.785 \\
\hline $\begin{array}{l}\text { Tracer } \\
\text { reassessment }\end{array}$ & $7(24.1 \%)$ & $4(13.8 \%)$ & 0.417 \\
\hline $\begin{array}{l}\text { Stent ejection } \\
\text { Stent }\end{array}$ & $5(17.2 \%)$ & $1(3.4 \%)$ & 0.085 \\
\hline $\begin{array}{l}\text { incomplete } \\
\text { distension }\end{array}$ & $0(0.0 \%)$ & $7(24.1 \%)$ & 0.005 \\
\hline TOTAL & $13(44.8 \%)$ & $19(65.5 \%)$ & 0.092 \\
\hline
\end{tabular}

\begin{tabular}{|c|c|c|c|}
\hline $\begin{array}{l}\text { early postpro- } \\
\text { cedural } \\
\text { complication }\end{array}$ & MPS & MNS & p \\
\hline cholangitis & $6(20.7 \%)$ & $12(41.4 \%)$ & 0.215 \\
\hline apscess & $0(0.0 \%)$ & $1(3.4 \%)$ & 0.067 \\
\hline $\begin{array}{l}\text { acute } \\
\text { cholecystitis }\end{array}$ & $1(3.4 \%)$ & $2(6.9 \%)$ & 0.337 \\
\hline perforatio & $0(0.0 \%)$ & $2(6.9 \%)$ & 0.052 \\
\hline $\begin{array}{l}\text { pleural } \\
\text { emphysema }\end{array}$ & $1(3.4 \%)$ & $1(3.4 \%)$ & 0.428 \\
\hline haemobilia & $2(6.9 \%)$ & 7 (24.1\%) & 0.000 \\
\hline $\begin{array}{l}\text { intraperitoneal } \\
\text { biloma }\end{array}$ & $2(6.9 \%)$ & $3(10.3 \%)$ & 0.856 \\
\hline $\begin{array}{l}\text { subcutaneous } \\
\text { metastasis }\end{array}$ & $0(0.0 \%)$ & $1(3.4 \%)$ & 0.364 \\
\hline $\begin{array}{l}\text { poststent } \\
\text { cholangitis }\end{array}$ & $3(10.3 \%)$ & $19(65.5 \%)$ & 0.000 \\
\hline $\begin{array}{l}\text { percutaneous } \\
\text { fistula }\end{array}$ & $1(3.4 \%)$ & $3(10.3 \%)$ & 0.226 \\
\hline stent occlusion & $0(0.0 \%)$ & $9(31.0 \%)$ & 0.001 \\
\hline $\begin{array}{l}\text { irritative } \\
\text { symptoms }\end{array}$ & $1(3.4 \%)$ & $29(100.0 \%)$ & 0.000 \\
\hline $\begin{array}{l}\text { loss of } \\
\text { appetite }\end{array}$ & $0(0.0 \%)$ & $6(20.7 \%)$ & 0.001 \\
\hline TOTAL & $13(44.8 \%)$ & $29(100.0 \%)$ & 0.000 \\
\hline
\end{tabular}

Table 2. Distribution of periprocedural complication

Table 3. Distribution of technical complication

Table 4. Distribution of early postptrocedural complication 
Table 5. Distribution of late postptrocedural complication

\begin{tabular}{|c|c|c|c|}
\hline $\begin{array}{l}\text { postproce- } \\
\text { durally late } \\
\text { complication }\end{array}$ & MPS & MNS & p \\
\hline $\begin{array}{l}\text { reobstructive } \\
\text { jundice }\end{array}$ & $4(14.3 \%)$ & 25 (100.0\%) & 0.000 \\
\hline $\begin{array}{l}\text { reobstructive } \\
\text { cholangitis }\end{array}$ & $4(14.3 \%)$ & 25 (100.0\%) & 0.000 \\
\hline $\begin{array}{l}\text { acute } \\
\text { cholecystitis }\end{array}$ & $0(0.0 \%)$ & $2(8.0 \%)$ & 0.066 \\
\hline $\begin{array}{l}\text { chronic } \\
\text { bleeding and } \\
\text { melena }\end{array}$ & $0(0.0 \%)$ & $4(16.0 \%)$ & 0.097 \\
\hline $\begin{array}{l}\text { duodenal } \\
\text { ulcer or } \\
\text { perforation }\end{array}$ & $0(0.0 \%)$ & $3(12.0 \%)$ & 0.117 \\
\hline $\begin{array}{l}\text { stent } \\
\text { migration } \\
\text { path forward }\end{array}$ & $2(7.1 \%)$ & $0(0.0 \%)$ & 0.173 \\
\hline pancreatitis & $0(0.0 \%)$ & $2(8.0 \%)$ & 0.236 \\
\hline $\begin{array}{l}\text { percutaneous } \\
\text { fistula }\end{array}$ & $0(0.0 \%)$ & $4(16.0 \%)$ & 0.104 \\
\hline $\begin{array}{l}\text { irritative } \\
\text { symptoms }\end{array}$ & $0(0.0 \%)$ & 24 (96.0\%) & 0.000 \\
\hline weith loss & $0(0.0 \%)$ & 7 (28.0\%) & 0.002 \\
\hline TOTAL & $6(21.4 \%)$ & 25 (100.0\%) & 0.000 \\
\hline
\end{tabular}

Table 6. Causes of stent dysfunctional

\begin{tabular}{|l|c|r|c|}
\hline $\begin{array}{l}\text { causes of } \\
\text { stent dys- } \\
\text { functional }\end{array}$ & MPS & \multicolumn{1}{|c|}{ MNS } & p \\
\hline $\begin{array}{l}\text { Obliteration } \\
\text { Ingrought }\end{array}$ & $0(0.0 \%)$ & $13(44.8 \%)$ & 0.000 \\
\hline $\begin{array}{l}\text { Overgrought } \\
\text { Mucosal } \\
\text { hiperplasia }\end{array}$ & $0(0.0 \%)$ & $8(27.6 \%)$ & 0.003 \\
\hline $\begin{array}{l}\text { Biliar } \\
\text { encrustation }\end{array}$ & $9(32.1 \%)$ & $13(44.8 \%)$ & 0.000 \\
\hline $\begin{array}{l}\text { TOTAL } \\
\text { TOTA }\end{array}$ & $9(32.1 \%)$ & $29(100.0 \%)$ & 0.325 \\
\hline
\end{tabular}

nant etiology are covered stents.

Low rate, technical and postprocedural complications, early and late, and low mortality rates, supports extraordinary therapeutic effects of a new generation of covered metallic stents, and differentiated polyurethane covered stents compared to uncovered stents as an almost ideal stretch. By all criteria, biocompatibility, this generation of stents proved to nititol stent mesh covered with silicone and polyurethane insert very successful, good in vivo tolerated without causing irritation and any complications, with very survival and durability of the therapeutic effects and preserving consistency within the tissue.

A retrospective review of 118 biliary stent endoprostheses placed in 113 patients
[12] assessed the frequency, nature, and treatability of significant complications. Mueller and associates reported early complication rate of $17 \%(19 / 113)$; the late complication rate of $31 \%(32 / 102)$. Some comparative studies [13] conducted by random - effects model, assessing the two types of stents: primary outcomes of interest were stent patency and patient survival; second outcomes included technical success, clinical success, tumor ingrowth, tumor overgrowth, and stent migration. According to that, 11 studies (8 randomized controlled trials and 3 prospective cohort studies) including a total of 1376 patientsthat identified. Covered SEMS were equivalent to bare self-expandable metal stent (SEMS) in terms of technical success, clinical success, stent patency (gastroduodenal obstruction: HR $=0.87,95 \%$ CI 0.53 1.42; colorectal obstruction: $\mathrm{HR}=0.89,95 \% \mathrm{CI}$ $0.18-4.45$; biliary obstruction: $\mathrm{HR}=0.73,95 \%$ CI 0.41-1.32) and survival rates (esophageal obstruction: $\mathrm{HR}=1.80,95 \%$ CI 0.73-4.44; gastroduodenal obstruction: $\mathrm{HR}=0.83,95 \%$ CI 0.55-1.26; biliary obstruction: $\mathrm{HR}=0.99,95 \%$ CI 0.77-1.28), although bare stents were more prone to tumor ingrowth (esophageal obstruction: $\mathrm{RR}=0.10,95 \%$ CI 0.01-0.77; gastroduodenal obstruction: $\mathrm{RR}=0.12,95 \%$ CI 0.03 0.55 ; colorectal obstruction: $\mathrm{RR}=0.21,95 \% \mathrm{CI}$ 0.06-0.70; biliary obstruction: $R R=0.21,95 \%$ CI 0.06-0.69), whereas covered stents had the higher risk of stent migration (gastroduodenal obstruction: $\mathrm{RR}=5.01,95 \%$ CI 1.53-16.43; colorectal obstruction: $\mathrm{RR}=11.70,95 \%$ CI 2.84 48.27; biliary obstruction: $\mathrm{RR}=8.11,95 \% \mathrm{CI}$ 1.47-44.76) and tumor overgrowth (biliary obstruction: $\mathrm{RR}=2.03,95 \%$ CI 1.08-3.78).

The research we have conducted on two groups, shown in table 1. demographic almost identical characteristics, diagnosis and general condition. This research has given us the opportunity to compare the therapeutic effects of two groups of stents to sample nearly identical groups of patients in virtually identical clinical conditions, monitoring of different categories of complications and causes of stent dysfunctional as direct and indirect parameters of stent biocompatibility. This minimally invasive approach, carried out radiologically as well as endoscopically, allows the narrowed viscus lumen to be kept patient, decreasing the obstructive impairment of the hepatobiliary and gastrointestinal function, with consequent relief of patient symptoms and improvement in quality of life [14-16]. However, complications 
may develop during positioning, usually being recognized immediately by the operator, or may be detected after placement by diagnostic imaging as early (first 30 days after placement) or late (> 30 days) events [13, 17-18].

To the extent periprocedural complications, bleeding was the only complication that significantly more frequent in uncovered stents illustrating the irritation uncovered versus covered metal stent to the surrounding tissue and therefore less conspicuous biocompatibidity.

As in most studies of biliary SEMS [19], technical placement success was almost universal. From the technical complications incomplete insertion is imposed by uncovered metal stents as significantly greater hindrance biocompatibility or achieving the expected therapeutic effect riched by technically correct insertion. In addition, noninserted on the proper way and the full diameter, the stent becomes a foreign body that can cause weight side effects and complications of the surrounding tissues and the body as a whole. Complications of this type are considered in the category of early and late postprocedural complication. As postprocedural early complications occurred up to one month after the intervention-hemobilia, poststent cholangitis, stent occlusion, irritative siptoms and loss of appetite are indicators statistically significant consequences of uncovered stents unbiocompatibility.

Superinfection is an important potential complication for patients with biliary stents. Superinfection includes cases of cholangitis and liver abscess [20] and according to literature; early infectious complications are less frequent with covered stents and in subjects with a stent in a transpapillary position [20, 21]. From those studies, liver abscess appeared in $0.3-0.5 \%$ cases; adequate is our result for MCS $0 \%$, but little bit higher in a case of MNS 3.4\%. Cholangitis described on a level of $0.3 \%-22 \%$, appears in almost the same level in our study - MCS $20.7 \%$, and higher in MNS 41.4\% (table 4). Cholecystitis described $1.9-12 \%$ in theliterature $[19,20]$, in our study is $3.4 \%$ for MCS, and $6.9 \%$ for MNS, as early complication and $0 \%$ for MCS, $8 \%$ for MNS as late postprocedural complication.

Reobstructive jundice, Reobstructive cholangitis, irritativ symptoms and weith loss from the fild of late postprocedural complication gave us the same conclusion. Although usually spontaneous, stent migration may sometime be caused by surgical, endoscopic, or percutaneous maneuvers [22]. Migration seems to occur more frequently with covered stents, probably because of their weaker anchorage, than with uncovered stents [14]. Stent migretion we evaluate in this complication category, and we found $7.1 \%$ in a case of covered stents (table 5). Our results is higher than results presented by some multicentric studies on the fild of stent migration; Kullman and coauthors reported 3\% migration rate in covered stent verus uncovered and also no patient with migration in uncoverd stent group as we considered during the period of 6 months [21]. Stent migration may cause obstruction, hemorrhage, and perforation [23] or may have no consequence. Haemobilia, in early complication group, and chronic bleeding and melena, in late complication group, are complication that can be associated with stent migration or irritation by the stent. Perforation can be free or covered and, depending on the anatomic site, may cause free peritoneal air and effusion, retroperitoneal gas spread, or fistula formation with other hollow organs and structures. In our study are described perforation as early complication (MPS 0\%, MNS 6.9\%) and duodenal ulcer and perforation, as late complication (MPS 0\%, MNS 12\%). Pancreatitis in our patients with MCS isn't appeared (0\%), but in MNS $8 \%$; information from literature is $2 \%$.

Stent obstruction can result from several causes including tumor regrowth through the mesh of an uncovered stent (i.e., ingrowth) or at its extremities (i.e., outgrowth), tissue hyperplasia (granulation tissue), luminal impaction, stent collapse or angulations, insufficient stent diameter, stent fracture, and stent migration [24]. In our study almost all of causses of stent affunction are in favor biocomatability of covered stents. We have no patient with obliteration, ingrought, overgrought and mucosal hiperplassia. Biliar encrustation is founded in MCS 32.1\%, in group of MNS 44.8\% (table 6). There is no significant diferensis between groups, but there is compering to literature. In most studies encrustation as biliary tract stenting complication is founded in 2-6\% complication reported [15-18].

Recurrent biliary obstruction caused by migration or stent occlusion remains the most important issue. It is still unproven whether coveredself-expandable metal stent (CSEMS) will be a better solution than uncovered SEMS as evidenced by 2 recently pub- 
lished randomized studies [21, 25]. Over the years the concept of covering metal stents with membranes has been discussed but controversiesexists, such as whether covered metal stents actually offer more durable biliary drainage and whether they lead to stent migration or complication and whether biocompatible to human body.

From all that reasons, we can conclude that covered metal stents are biocompatible with the human body. Biocompatibility of covered metal stents in the treatment of irreversible halt bile is evident if we consider that it is a very complex pathological entity, which in the case of selected patients malignant etiology, followed by a very severe clinical picture, which is very fast due to hemodynamic imbalance can result in vital vulnerability, regardless of the stage of disease. Such conditions require prompt medical attention by choosing effective treatment methods to eliminate vital threat in the shortest possible time, without having to be less invasive and harmful to the patient. Judging by the results of applied new generation stents, stents meet a number of quality that they can be placed in order to measure the most effective treatment now.

Qualities that favor covered biliary stents over all previous methods of interventional radiology treatment as an earlier generation stents and other are:

1. Provide long-term lumen patency and ingrowth into the wall of the gall road or obstruction secondary proliferative tissue is physically possible;

2. Well tolerated non-irritant;

3. Not change position after installation-not migrate;

4. Stent implantation is performed on an outpatient under local anesthesia.

Insertion success, duration of adequate clinical palliation, and complications were all superior or comparable to most published data on self-expanding biliary stents. Results are visible immediately, depending on the severity of cholestasis, return to normal skin color in patients to improve the general condition and hemodynamic stabilization performed promptly, in the same time with the establishment of runoff captured bile juices. The scientific contribution is justified by the fact that this generation of stents has never before been applied, so it provides a genuine therapeutic solution.

\section{CONCLUSION}

According to our results, taking into account the parameters of biocompatibility under applicable definitions, authors can conclude that covered stents in contrast to the uncovered are meeting the criteria of almost ideal biological prostheses.

\section{REFERENCES}

1. Black J. Biological performance of materials: fundamentals of biocompatibility. CRC Taylor \& Francis, Boca Raton, 2006.

2. Hegyeli RJ (ed.) Proceedings of the Artificial Heart Program Conference. U.S. Government Printing Office, Washington D.C., 1969.

3. Homsy CA, Ansevin KD, O’Bannon W, Thompson SA, Hodge R, Estrella M. J Macromol Sci (Chem). 1970; 4 (3):615-34.

4. Williams DF. On the mechanisms of biocompatibility. Biomaterials 2008; 29(20):941-53.

5.Williams DF. The Williams dictionary of biomaterials. Liverpool University press, Liverpool, 1999.

6. Williams D. Revisiting the definition of biocompatibility. Med Device Technol. 2003; 14(8):10-3.

7. Kammula RG, Morris JM. Considerations for the biocompatibility evaluation of medical devices. Medical Device \& Diagnostic Industry, May 2001.

8. Müller U. In vitro biocompatibility testing of biomaterials and medical devices. Med Device Technol. 2008; 19(2):32-4.

9. Mahajan A, Ho H, Jain A, Rehan ME, Northup PG, Phillips MS, Ellen K, Shami VM, Kahaleh M. Mortality in patients undergoing covered self-expandable metal stent revisions in malignant biliary stricture: does pathology matter? Dig Liver Dis. 2010; 42(11):803-6.

10. Togawa O, Kawabe T, Isayama H, Nakai Y, Sasaki T, Arizumi T, Matsubara S, Ito Y, Yamamoto N, Sasahira N, Hirano K, Tsujino T, Toda N, Tada M, Yoshida $\mathrm{H}$, Omata M. Management of occluded uncovered metallic stents in patients with malignant distal biliary obstructions using covered metallic stents. J Clin Gastroenterol. 2008; 42(5):546-9.

11. European Parliament and the Council of the European Union. Directive 2001/20/EC of the European Parliament and of the Council of 4 April 2001 on the approximation of the laws, regulations and administrative provisions of the Member States relating to the implementation of good clinical practice in the conduct of clinical trials on medicinal products for human use. Available from: https:// ec.europa.eu/health/sites/health/files/files/ eudralex/vol-1/dir_2001_20/dir_2001_20_en.pdf 
12. Mueller PR, Ferrucci JT Jr, Teplick SK, van Sonnenberg E, Haskin PH, Butch RJ, Papanicolaou N. Biliary stent endoprosthesis: analysis of complications in 113 patients. Radiology 1985; 156(3):637-9.

13. Yang Z, Wu Q, Wang F, Ye X, Qi X, Fan D. A systematic review and meta-analysis of randomized trials and prospective studies comparing covered and bare self-expandable metal stents for the treatment of malignant obstruction in the digestive tract. Int J Med Sci. 2013; (7):825-35.

14. Chun HJ, Kim ES, Hyun JJ, Kwon YD, Keum B, Kim CD. Gastrointestinal and biliary stents. J Gastroenterol Hepatol. 2010; 25:234-43.

15. Katsanos K, Sabharwal T, Adam A. Stenting of the upper gastrointestinal tract: current status. Cardiovasc InterventRadiol. 2010; 33:690-705.

16. Katsanos K, Sabharwal T, Adam A. Stenting of the lower gastrointestinal tract: current status. Cardiovasc InterventRadiol2011; 34:462-73.

17. Kullman E, Frozanpor F, Söderlund C, et al. Covered versus uncovered self-expandable nitinol stents in the palliative treatment of malignant distal biliary obstruction: results from a randomized, multicenter study. GastrointestEndosc2010; 72:915-23.

18. Kim JH, Song H-Y, Shin JH, et al. Stent collapse as a delayed complication of placement of a covered gastroduodenal stent. Am J Roentgenol. 2007; 188:1495-99.

19. Petersen BT, Kahaleh M, Kozarek RA, Loren D, Gupta K, Kowalski T, Freeman M, Chen YK, Branch MS, Edmundowicz S, Gluck M, Binmoeller K, Baron TH, Shah RJ, Kinney T, Ross W, Jowell P, Carr-Locke D. A multicenter, prospective study of a new fully covered expandable metal biliary stent for the palliative treatment of malignant bile duct obstruction. Gastroenterol Res Pract. 2013; vol 2013, Article ID 642428, 7 pages. doi:10.1155/2013/642428

20. Li Sol Y, Kim CW, Jeon UB, Lee NK, Kim S, Kang $\mathrm{DH}$, Kim GH. Early infectious complications of percutaneous metallic stent insertion for malignant biliary obstruction. Am J Roentgenol. 2010; 194(1):261-5.

21. Kullman E, Frozanpor F, Söderlund C, Linder S, Sandström P, Lindhoff-Larsson A, Toth E, Lindell G, Jonas E, Freedman J, Ljungman M, Rudberg C, Ohlin $\mathrm{B}$, Zacharias R, Leijonmarck CE, Teder K, Ringman A, Persson G, Gözen M, Eriksson O. Covered versus uncovered self-expandable nitinol stents in the palliative treatment of malignant distal biliary obstruction: results from a randomized, multicenter study. Gastrointest Endosc. 2010; 72(5):915-23.

22. Brinkley M, Wible BC, Hong K, Georgiades C. Colonic perforation by a percutaneously displaced biliary stent: report of a case and a review of current practice. J VascIntervRadiol. 2009; 20:680-3.

23. Görich J, Rilinger N, Krämer S, Aschoff AJ, Vogel J, Brambs HJ, Sokiranski R. Displaced metallic biliary stents: technique and rationale for interventional radiologic retrieval. Am J Roentgenol 1997; 169(6):1529-33.

24. Phillips MS, Gosain S, Bonatti H, Friel CM, Ellen $\mathrm{K}$, Northup PG, Kahaleh $M$. Enteral stents for malignancy: a report of 46 consecutive cases over 10 years, with critical review of complications. J Gastrointest Surg. 2008; 12(11):2045-50.

25. Telford JJ, Carr-Locke DL, Baron TH, Poneros JM, Bounds BC, Kelsey PB, Schapiro RH, Huang CS, Lichtenstein DR, Jacobson BC, Saltzman JR, Thompson CC, Forcione DG, Gostout CJ, Brugge WR. A randomized trial comparing uncovered and partially covered self-expandable metal stents in the palliation of distal malignant biliary obstruction. GastrointestEndosc. 2010; 72(5):907-14. 


\title{
Biokompatibilnost nove generacije prekrivenih metalnih žučnih stentova u lečenju nepovratne holestaze maligne etiologije
}

\author{
Vesna M.Vilendečić ${ }^{1}$, Željko Ž. Markovićn ${ }^{1,2}$, Biljana B. Marković Vasiljkovići, ${ }^{1,2}$ \\ Dragan M. Mašulović1,2 \\ ${ }^{1}$ Klinički centar Srbije, Centar za radiologiju i magnetnu rezonancu, 11000 Beograd, Srbija \\ ${ }^{2}$ Univerzitet u Beogradu Medicinski fakultet, 11000 Beograd, Srbija
}

\section{KRATAK SADRŽAJ}

Uvod: Pregled periproceduralnih i postproceduralnih (ranih i kasnih) komplikacija daju nam mogućnost da determinišemo biološke efekete lečenje prekrivenim u poređenju sa neprekrivenim metalnim stentovima kod pacijenata sa nepovratnom žuticom maligne etiololgije.

Cilj: Cilj studije je komparacija kliničko-terapeutskih efekata pokrivenih bilijarnih stentova u odnosu na nepokrivene bilijarne stentove.

Metodologija: Tretirali smo dve grupe bolesnika sa ireverzibilnom holestazom maligne etiologije. Prvu grupu bolesnika smo lečili metalnim prekrivenim stentovima (MPS), dok smo drugu grupu bolenika (MNS) lečili metalnim neprekrivenim stentovima.

Rezultati: Pratili smo periproceduralne komplikacije, tehničke komplikacije, postproceduralne komplikacije, rane-do 30 dana i kasne-do 6 meseca, kao i parametre biokompatibilnosti ubačene endoproteze, odnosno biološke efekte na okolna tkiva. Pronašli smo statistički značajnu razliku u pojavi krvarenja i periproceduralne komplikacije u ukupnoj grupi MNS. U kategoriji ranih postproceduralnih komplikacija, našli smo statistički značajnu razliku u MNS grupama za hemobiliju, poststentni holangitis, okluziju stenta, iritantne simptome i gubitak apetita, kao i u ukupnom izgledu ranih postproceduralnih komplikacija u MNS-u. U kategoriji kasnih postproceduralnih komplikacija statistički značajne razlike smo našli u MNS reopstruktivnom holangitisu, reopstruktivnoj žutici, iritantnim simptomima, nedostataku apetita i takođe kod celokupne pojave ranih postproceduralnih komplikacija kod MNS. Uzrok afunkcije stenta-obliteracija, bilijarna incrustacija, urastanje, obrastanje i mukozna hiperplazija, govore nam u korist bioloških efekata ubacivanja primenjene proteze i konačnog terapijskog efekta koji su oni postigli.

Zaključak: Prema rezultatima ove studije, uzimajući u obzir parametre biokompatibilnosti prema važećim definicijama, autori zaključuju da prekriveni stentovi, za razliku od neprekrivenih stentova, ispunjavaju kriterijime gotovo idealnih bioloških proteza.

Ključne reči: metalni prekriveni stent, metalni neprekriveni stent, biokompatibilnost, biološki efekti, biološki sistem, ireverzibilna holestaza, maligna etiologija 